Supporting Information

\title{
Impact of Phosphate on Iron Mineralization and Mobilization in Non-heme Bacterioferritin B from Mycobacterium tuberculosis
}

\author{
Akankshika Parida ${ }^{1}$, Abhinav Mohanty ${ }^{1}$, Bharat T. Kansara, ${ }^{2}$ Rabindra K. Behera ${ }^{1 *}$ \\ ${ }^{1}$ Department of Chemistry, National Institute of Technology, Rourkela - 769008, Odisha, India. \\ ${ }^{2}$ Tata Institute of Fundamental Research, Homi Bhabha Road, Colaba, Mumbai 400005, India.
}

*To whom correspondence should be addressed: Rabindra K. Behera, Tel: +91-661-2462980;

Fax: +91-661-2462651; E-mail: beherarabi@nitrkl.ac.in 
Table S1. Half-lives of the catalytic transient intermediate at different Fe/cage

\begin{tabular}{cccc}
\hline Fe/cage & Decay rate constant $(\mathrm{k}), \mathrm{s}^{-1}$ & Average lifetime $(\mathrm{T}), \mathrm{s}$ & Half-life $\left(\mathrm{t}_{1 / 2}\right), \mathrm{s}$ \\
\hline 24 & 2.8 & 0.36 & 0.25 \\
48 & 4.48 & 0.22 & 0.15 \\
72 & 5.05 & 0.20 & 0.14 \\
96 & 5.06 & 0.20 & 0.14 \\
120 & 5.47 & 0.18 & 0.13 \\
192 & 5.48 & 0.18 & 0.13 \\
240 & 5.56 & 0.18 & 0.12 \\
360 & 5.84 & 0.17 & 0.12 \\
480 & 6.79 & 0.15 & 0.10 \\
\hline
\end{tabular}

The decay rate constants were calculated by fitting the decay part of the $\Delta \mathrm{A}_{650 \mathrm{~nm}}$ progress curves in Fig. 2A to the first exponential equation, $A_{t}=A_{0} \cdot \exp (-k t)+A_{\infty}$, for all the Fe/cage ratios. The data are averages of two sets of independent experiments using two different protein preparations. Final concentration of $M t b$ BfrB was $2.08 \mu \mathrm{M}$ in $100 \mathrm{mM}$ MOPS, $100 \mathrm{mM} \mathrm{NaCl}$ ( $\mathrm{pH}$ 7.0).

Table S2. Kinetic parameters of catalytic transient intermediate and $\left[\mathrm{Fe}^{3+}-\mathrm{O}\right]_{\mathrm{x}}$ species under different phosphate concentrations

\begin{tabular}{|c|c|c|c|c|}
\hline \multicolumn{3}{|c|}{ Catalytic transient intermediate } & \multicolumn{2}{|c|}{$\left[\mathrm{Fe}^{3+}-\mathrm{O}\right]_{\mathrm{x}}$ species } \\
\hline $\mathrm{P}_{\mathrm{i}}(\mathrm{mM})$ & \multicolumn{2}{|c|}{$48 \mathrm{Fe} /$ cage } & $48 \mathrm{Fe} /$ cage & $480 \mathrm{Fe} / \mathrm{cage}$ \\
\hline & $\Delta \mathrm{A}_{650 \mathrm{~nm}} / \Delta \mathrm{t}, \mathrm{s}^{-1}$ & Half-life $\left(t_{1 / 2}\right), s$ & $\Delta \mathrm{A}_{350 \mathrm{~nm}} / \Delta \mathrm{t}, \mathrm{s}^{-1}$ & $\Delta \mathrm{A}_{350 \mathrm{~nm}} / \Delta \mathrm{t}, \mathrm{s}^{-1}$ \\
\hline 0 & 0.36 & 0.132 & 0.84 & 2.02 \\
\hline 1 & 0.39 & 0.128 & 0.86 & 2.55 \\
\hline 5 & 0.40 & 0.123 & 0.93 & 3.42 \\
\hline 10 & 0.43 & 0.120 & 0.97 & 4.14 \\
\hline
\end{tabular}

The decay rate constants were calculated by fitting the decay part of the $\Delta \mathrm{A}_{650 \mathrm{~nm}}$ progress curves to the first exponential equation, $A_{t}=A_{0} \cdot \exp (-k t)+A_{\infty}$, for all the phosphate concentrations. Final concentration of $M t b$ BfrB was $2.08 \mu \mathrm{M}$ in Fig. 2A,B and $1.04 \mu \mathrm{M}$ in Fig. 2C,D in 100 $\mathrm{mM}$ MOPS, $100 \mathrm{mM} \mathrm{NaCl}(\mathrm{pH}$ 7.0). The data reported are averages of two independent experiments using two protein preparations. 
Table S3. Comparison of decay constants and maxima for DFP like transient species in different ferritins

\begin{tabular}{|c|c|c|}
\hline Ferritin & Decay rate constant $(\mathrm{k}), \mathrm{s}^{-1}$ & Maxima for DFP/DFP like species \\
\hline$M t b$ BfrB & $4.48 \pm 0.03$ & $\sim 50 \mathrm{~ms}$ \\
\hline$M t b$ BfrA & $1.22 \pm 0.03$ & $\sim 300 \mathrm{~ms}$ \\
\hline
\end{tabular}

The data listed here are/were calculated for $48 \mathrm{Fe} / \mathrm{cage}$. For $M t b \mathrm{BfrB}$, the decay constants were calculated from Fig. 2A using the first exponential equation as described in the methods section.

Table S4. Effect of iron loading and phosphate on $\mathrm{Fe}^{2+} / \mathrm{O}_{2}$ stoichiometry, $\mathrm{O}_{2}$ evolution/peroxide formation by Mtb BfrB by oximetry assay.

\begin{tabular}{|c|c|c|c|c|c|c|c|c|c|c|c|}
\hline \multicolumn{10}{|c|}{$\mathrm{Fe}^{2+} / \mathrm{O}_{2}$ stoichiometry } & \multicolumn{2}{|c|}{$12 \mathrm{Fe} / \mathrm{cage}$} \\
\hline $\begin{array}{c}\text { Fe/cage } \\
\rightarrow\end{array}$ & 6 & 12 & 24 & 36 & 48 & $\begin{array}{c}\stackrel{\text { Fe/cage }}{\rightarrow} \\
\mathrm{P}_{\mathrm{i}}, \mathrm{mM} \downarrow\end{array}$ & 48 & 240 & 480 & $\begin{array}{c}\mathrm{Fe}^{2+} / \mathrm{O}_{2} \\
\text { stoichiometry }\end{array}$ & $\begin{array}{c}\text { Evolved } \\
\mathrm{O}_{2} \\
(\mu \mathrm{M})^{* *}\end{array}$ \\
\hline & 1.5 & 1.5 & 1.6 & 1.7 & 1.9 & 0 & 1.9 & 2.4 & 2.7 & 1.6 & 2.9 \\
\hline & \multirow{2}{*}{\multicolumn{5}{|c|}{ Evolved $\mathrm{O}_{2}(\mu \mathrm{M})^{*}$}} & 1 & 1.7 & 2.2 & 2.3 & 1.5 & 2.8 \\
\hline & & & & & & 5 & 1.3 & 1.9 & 2.2 & 1.3 & 2.7 \\
\hline & 2.0 & 3.0 & 4.6 & 2.6 & 1.9 & 10 & 1.2 & 1.8 & 2.1 & 1.1 & 2.6 \\
\hline
\end{tabular}

The $\mathrm{Fe}^{2+} / \mathrm{O}_{2}$ stoichiometry (extreme left) were calculated from the oxygen consumption curves in Fig.4C. The $\mathrm{Fe}^{2+} / \mathrm{O}_{2}$ stoichiometry, under varying concentrations of phosphate for different iron loading are calculated from Fig.4A,B \& Fig.S3 (center) and for 12 Fe/cage (right), were calculated from the oximetry analysis in Fig.S4A.

Evolved $\mathrm{O}_{2}$ quantified by oximetry analysis upon addition of catalase to estimate $\mathrm{H}_{2} \mathrm{O}_{2}$ generation during ferroxidase activity of $M t b \mathrm{BfrB}$ with: *varying Fe/cage and ** $12 \mathrm{Fe} / \mathrm{cage}$. 
Table S5. Quantitative and qualitative estimation of iron loading under increasing phosphate concentrations. $\mathrm{FeSO}_{4}(1 \mathrm{mM})$ was added to $\mathrm{BfrB}(2.08 \mu \mathrm{M}$ cage $)$ along with phosphate (1-10 $\mathrm{mM})$ during the iron mineralization.

\begin{tabular}{|c|c|c|c|}
\hline \multirow{2}{*}{$\begin{array}{c}\text { Phosphate } \\
(\mathbf{m M}) \downarrow\end{array}$} & $\begin{array}{c}\text { Ferrozine Assay } \\
\text { (Fe/cage) }\end{array}$ & $\begin{array}{c}\text { Native-PAGE }^{* *} \\
\text { (Reduction in intensity of } \\
\text { bands in Prussian staining) } \\
\text { (in \%) }\end{array}$ & $\begin{array}{c}\text { TEM }^{* *} \\
\text { (Reduction in core } \\
\text { diameter) } \\
\text { (in nm) }\end{array}$ \\
\hline 0 & $401 \pm 21$ & $100 \pm 6$ & $5.3 \pm 0.1$ \\
\hline 1 & $368 \pm 20$ & $74 \pm 8$ & $4.3 \pm 0.1$ \\
\hline 5 & $271 \pm 11$ & $73 \pm 4$ & $3.7 \pm 0.2$ \\
\hline 10 & $208 \pm 19$ & $53 \pm 6$ & $3.0 \pm 0.1$ \\
\hline
\end{tabular}

Quantification via formation of $\left[\mathrm{Fe}(\mathrm{Fz})_{3}\right]^{4-}{ }^{* *}$ Normalized values from ImageJ analysis.

Table S6. Elemental composition obtained from EDX spectra of mineralized recombinant WT Mtb BfrB protein nanocages doped with variable phosphate content $(0-10 \mathrm{mM})$.

\begin{tabular}{|c|c|c|c|}
\hline $\begin{array}{c}\text { Mineralized Mtb } \\
\text { BfrB samples with } \\
\text { phosphate doping of }\end{array}$ & $\begin{array}{c}\text { Iron } \\
\text { (Fe; Normalized atom \%) }\end{array}$ & $\begin{array}{c}\text { Phosphorous } \\
\text { (P; Normalized atom \%) }\end{array}$ & Fe: P \\
\hline $0 \mathrm{mM}$ & $3.54 \pm 0.83$ & $0.06 \pm 0.01$ & 59 \\
\hline $1 \mathrm{mM}$ & $1.76 \pm 0.32$ & $0.49 \pm 0.11$ & 3.59 \\
\hline $5 \mathrm{mM}$ & $0.99 \pm 0.48$ & $4.41 \pm 2.04$ & 0.22 \\
\hline $10 \mathrm{mM}$ & $7.66 \pm 1.13$ & $8.06 \pm 0.73$ & 0.95 \\
\hline
\end{tabular}

Table S7. Initial rate of iron release (formation of $\left[\mathrm{Fe}(\mathrm{Fz})_{3}\right]^{--}$) at different phosphate concentrations (set ' $\mathbf{b}$ ') employed for reductive mobilization of iron from ferritin.

\begin{tabular}{|c|c|c|c|c|}
\hline \multirow{2}{*}{$\begin{array}{c}\text { Phosphate } \\
(\mathbf{m M})\end{array}$} & \multicolumn{4}{|c|}{ Average Rate $\left(\boldsymbol{\mu M} \mathbf{~ m i n}^{-1}\right)$} \\
\cline { 2 - 5 } & Before $\mathbf{P}_{\mathbf{i}}$ removal & \multicolumn{2}{c|}{ After $\mathbf{P}_{\mathbf{i}}$ removal } \\
\cline { 2 - 5 } & Initial Lag Phase & Rapid Phase & $\begin{array}{c}\text { Initial Lag } \\
\text { Phase }\end{array}$ & Rapid Phase \\
\hline 0 & $0.083 \pm 0.010$ & $1.382 \pm 0.26$ & $0.079 \pm 0.012$ & $1.654 \pm 0.35$ \\
\hline 1 & $0.045 \pm 0.004$ & $0.785 \pm 0.38$ & - & $0.865 \pm 0.42$ \\
\hline 5 & $0.013 \pm 0.002$ & $0.456 \pm 0.54$ & - & $0.372 \pm 0.61$ \\
\hline 10 & $0.002 \pm 0.001$ & $0.172 \pm 0.74$ & - & $0.264 \pm 0.76$ \\
\hline
\end{tabular}




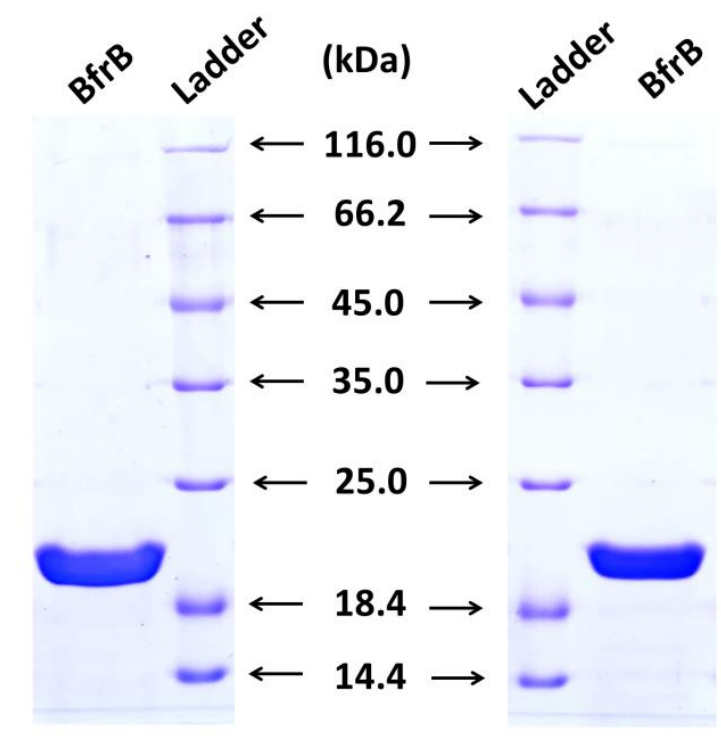

Preparation 1

Preparation 2

Figure S1. The purified Mtb BfrB ( 20.4 kDa, 181 amino acids) on a $12.5 \%$ of SDS polyacrylamide gel (two preparations). The molecular weights (in $\mathrm{kDa}$ ) of the ladder are indicated at the center.
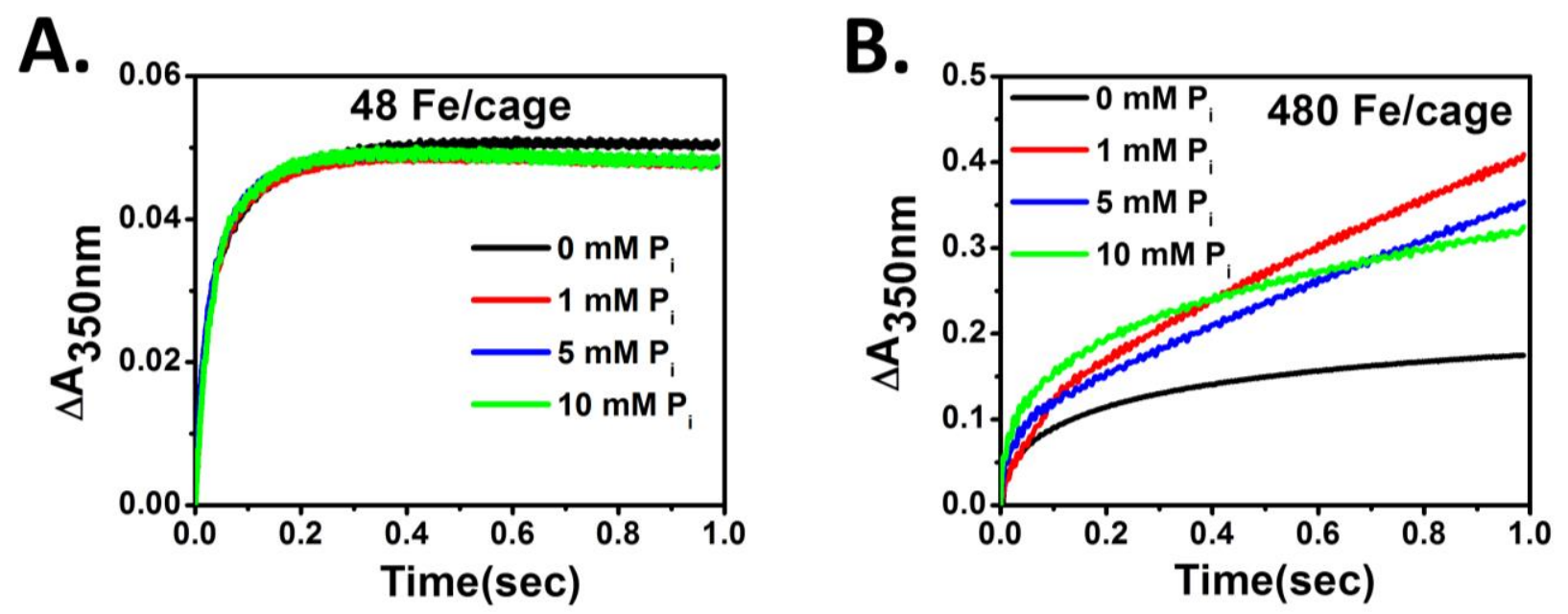

Figure S2. Effect of phosphate on $M t b$ BfrB catalyzed iron mineralization reaction. Stopped flow rapid kinetic measurements of iron oxidation by $M t b$ BfrB in the presence of $0-10 \mathrm{mM}$ phosphate, for the formation of $\left[\mathrm{Fe}^{3+}-\mathrm{O}\right]_{\mathrm{x}}$ species at $350 \mathrm{~nm}$ during single catalytic turnover (48 Fe/cage) (A) and multiple catalytic turnover (480 Fe/cage) (B). Phosphate in the range of 0-20 $\mathrm{mM}$ was incubated with $4.16 \mu \mathrm{M}$ (for $48 \mathrm{Fe} /$ cage) and $2.08 \mu \mathrm{M}$ (480 Fe/cage) of $\mathrm{Mtb} \mathrm{BfrB}$ followed by rapid mixing with an equal volume of freshly prepared ferrous sulfate in a stopped- 
flow spectrophotometer. The reactions were carried out in $100 \mathrm{mM}$ MOPS buffer containing 100 $\mathrm{mM} \mathrm{NaCl}(\mathrm{pH} 7.0)$ at room temperature.
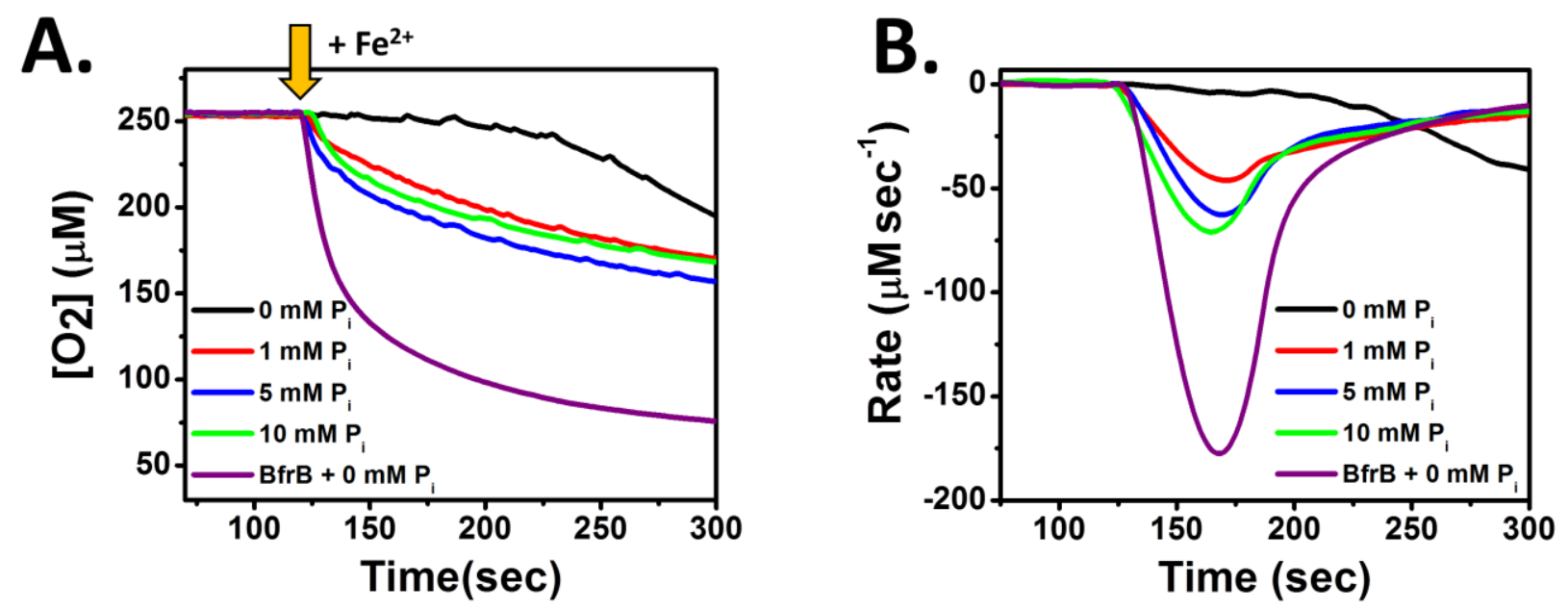

Figure S3. (A) Comparison of the oxygen consumption curves of autoxidation of iron under different concentrations of phosphate without $M t b \mathrm{BfrB}$ and the catalytic oxidation of $\mathrm{Fe}^{2+}$ by $M t b$ BfrB. (B) The rates of $\mathrm{O}_{2}$ consumption for the kinetic curves in panel A. For autoxidation reaction, $480 \mu \mathrm{M}$ of freshly prepared $\mathrm{FeSO}_{4}$ was added to the buffer pre-incubated with desired concentrations of phosphate. For the catalytic oxidation by $\mathrm{BfrB}, 480 \mu \mathrm{M}$ of $\mathrm{FeSO}_{4}$ was added to $1 \mu \mathrm{M}$ protein (cage concentration) to result in $480 \mathrm{Fe} / \mathrm{cage}$. The assay was carried out in $100 \mathrm{mM}$ MOPS, $100 \mathrm{mM} \mathrm{NaCl}(\mathrm{pH} 7.0)$ at room temperature.
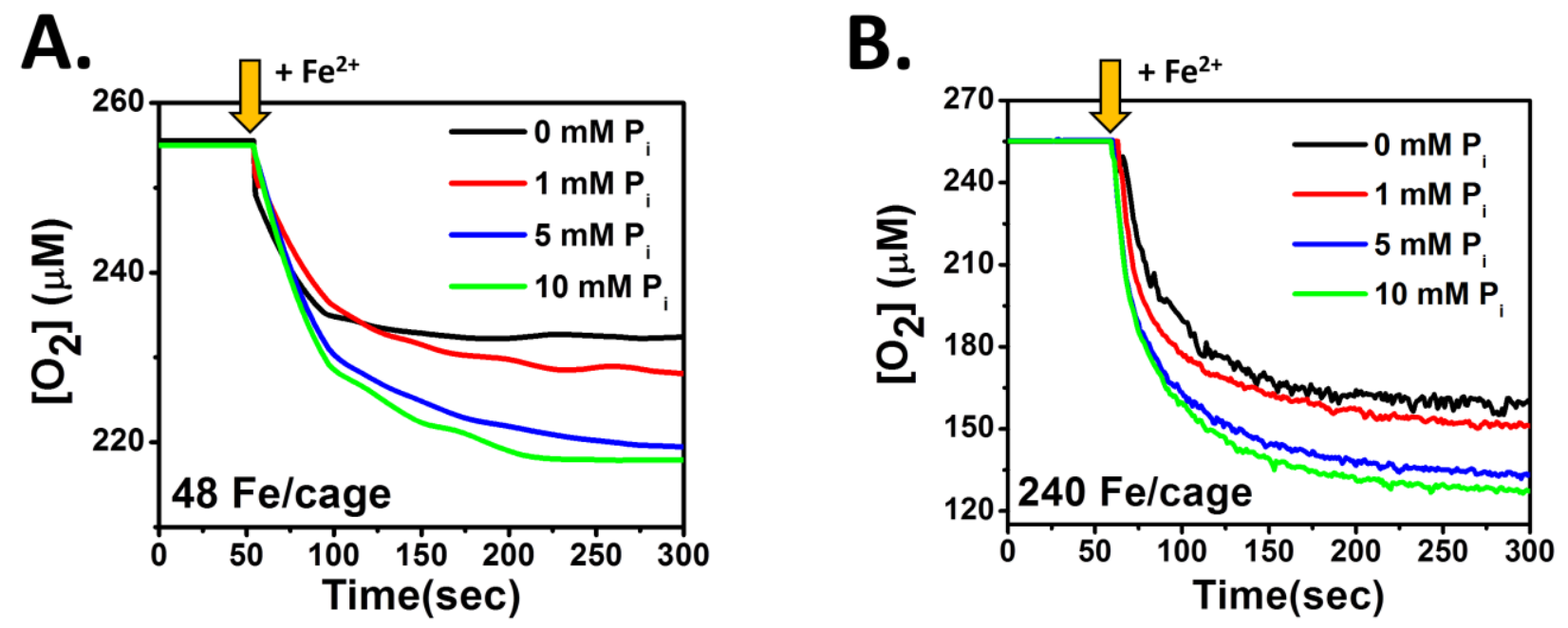

Figure S4. Effect of iron and phosphate on $\mathrm{O}_{2}$ consumption during the ferroxidase activity of Mtb BfrB. (A) $48 \mathrm{Fe} /$ cage (B) $240 \mathrm{Fe} / \mathrm{cage}$. To begin the ferroxidase reaction, $\mathrm{Fe}^{2+}$ ions were 
added to $1 \mu \mathrm{M}$ Mtb BfrB (100 mM MOPS, $100 \mathrm{mM} \mathrm{NaCl}$, pH 7.0) using Hamilton syringe to achieve 48 and $240 \mathrm{Fe} / \mathrm{cage}$. The time points of addition of $\mathrm{Fe}^{2+}$ ions are indicated by the arrows in yellow.
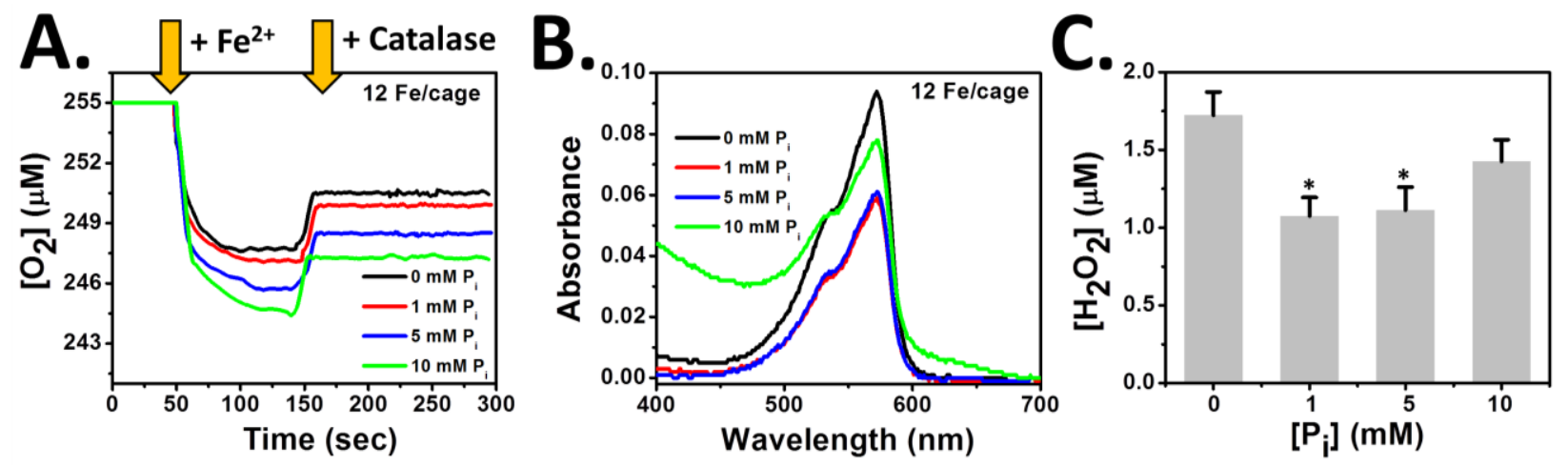

Figure S5. Detection of $\mathrm{H}_{2} \mathrm{O}_{2}$ generated during the ferroxidase activity of $M t b \mathrm{BfrB}$ in presence of variable amounts of phosphate by oximetry assay (A) and by Amplex Red/HRP assay (B). The effect of phosphate on $\mathrm{H}_{2} \mathrm{O}_{2}$ generation was monitored by oximetry analysis (addition of Catalase, panel ' $A$ ' and the formation of resorufin, panel ' $\mathbf{B}$ ' $\left(\varepsilon=5.4 \times 10^{4} \mathrm{M}^{-1} \mathrm{~cm}^{-1}\right.$ at $\left.571 \mathrm{~nm}\right)$ (see Methods). (C) The amount of $\mathrm{H}_{2} \mathrm{O}_{2}$ quantified from 'B'. The BfrB protein cage concentration was fixed at $1 \mu \mathrm{M}$ and phosphate was added to the protein samples prior to the addition of $\mathrm{Fe}^{2+}$ and was pre-incubated for 30 mins. The assays were carried out in $100 \mathrm{mM}$ MOPS, $100 \mathrm{mM} \mathrm{NaCl}(\mathrm{pH} 7.0)$ at $25^{\circ} \mathrm{C}$. The time points of addition of $\mathrm{Fe}^{2+}$ and catalase are indicated by the arrows in yellow.

${ }^{*} p<0.05$ w.r.t. $0 \mathrm{mM} \mathrm{P}$ and $p>0.05$ when compared between $1 \& 5 \mathrm{mM} \mathrm{P}$. 


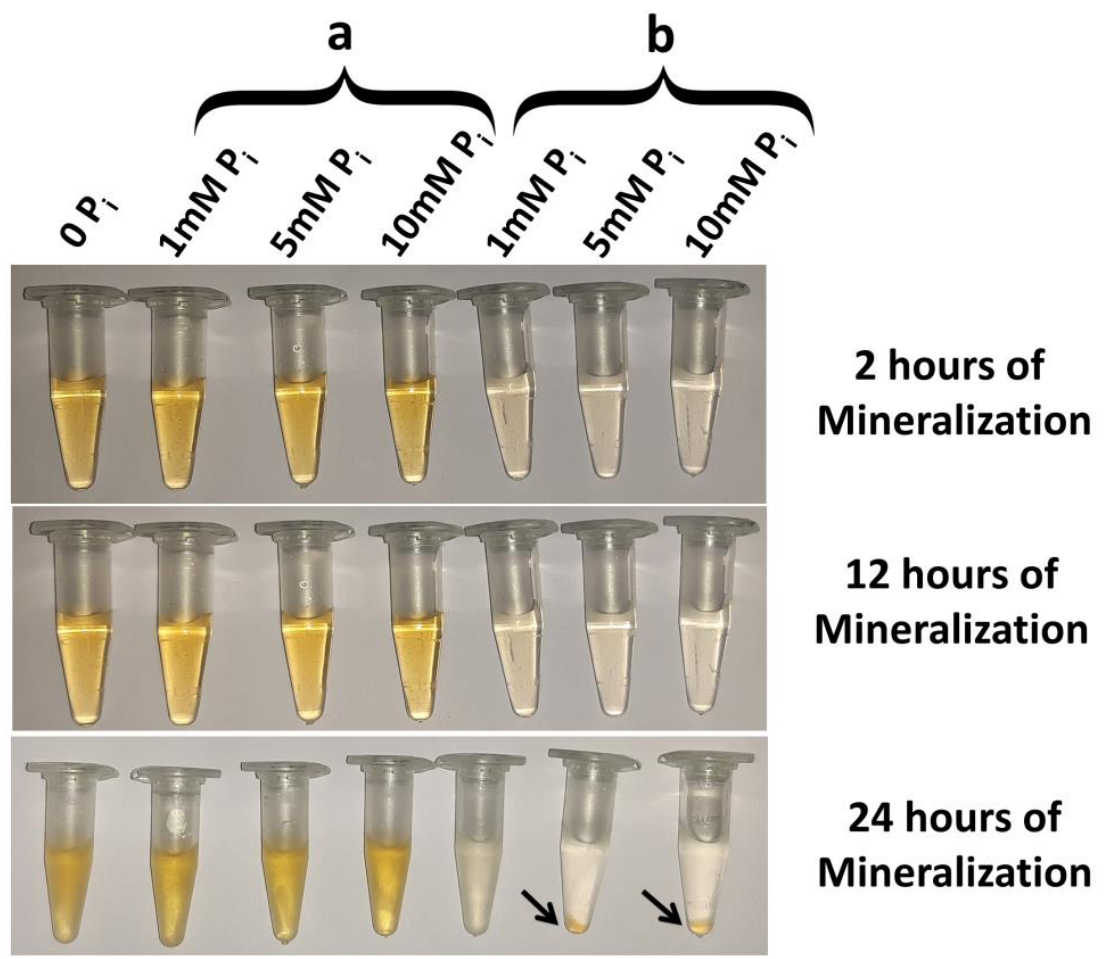

Figure S6. $M t b$ BfrB catalyzed iron mineralization reaction under different phosphate concentrations. set ' $\mathbf{a}$ ' corresponds to the phosphate addition to mineralized ferritin (i.e., after overnight incubation) and set ' $\mathbf{b}$ ' corresponds to the simultaneous addition of phosphate along with iron loading. The formation of insoluble $\mathrm{Fe}^{3+}-\mathrm{P}_{\mathrm{i}}$ precipitation was observed in case of 5 and $10 \mathrm{mM}$ phosphate after 24 hours of mineralization involving the simultaneous addition of both iron and phosphate. 

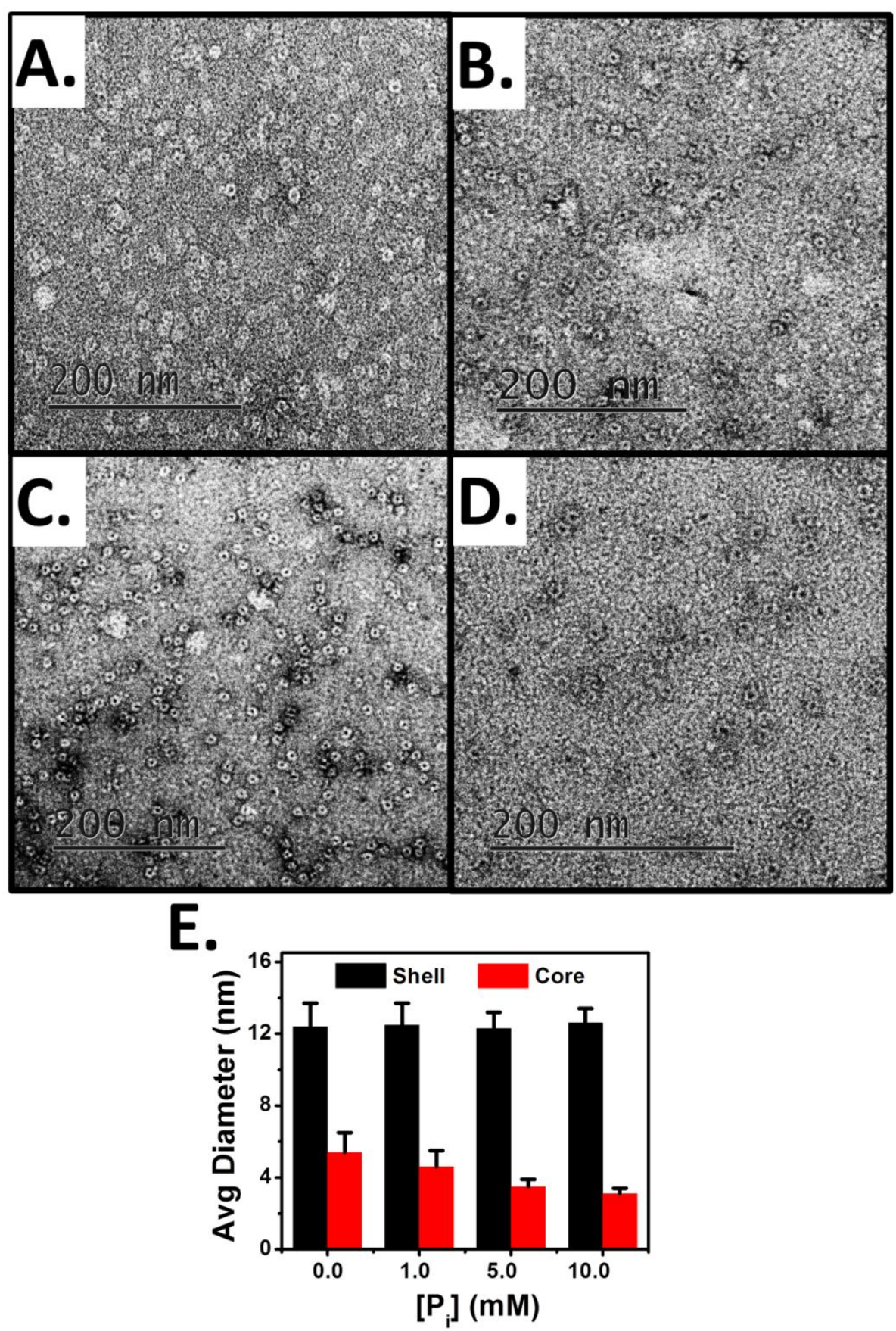

Figure S7. Iron loading and mineral formation under different phosphate concentrations using TEM. TEM image of mineralized recombinant $M t b$ BfrB nanocages prepared with various concentrations of phosphate: $0 \mathrm{mM}(\mathbf{A}) ; 1 \mathrm{mM}(\mathbf{B}) ; 5 \mathrm{mM}(\mathbf{C})$ and $10 \mathrm{mM}(\mathbf{D})$. The protein concentrations were maintained at $1 \mathrm{mg} / \mathrm{mL}$, loaded with $480 \mathrm{Fe} /$ cage and mentioned amount of phosphate. These iron and phosphate loaded ferritin protein samples were negatively stained with $1 \%(\mathrm{w} / \mathrm{v})$ gadolinium acetate tetrahydrate (uranyl acetate alternative) solution. Scale bars 
are $200 \mathrm{~nm}$ as indicated at the bottom left hand side of each panel (A-D). (E) Histogram representing the average size distribution of the iron mineral core and the shell of $M t b \mathrm{BfrB}$ protein nanocages as a function of phosphate loading.

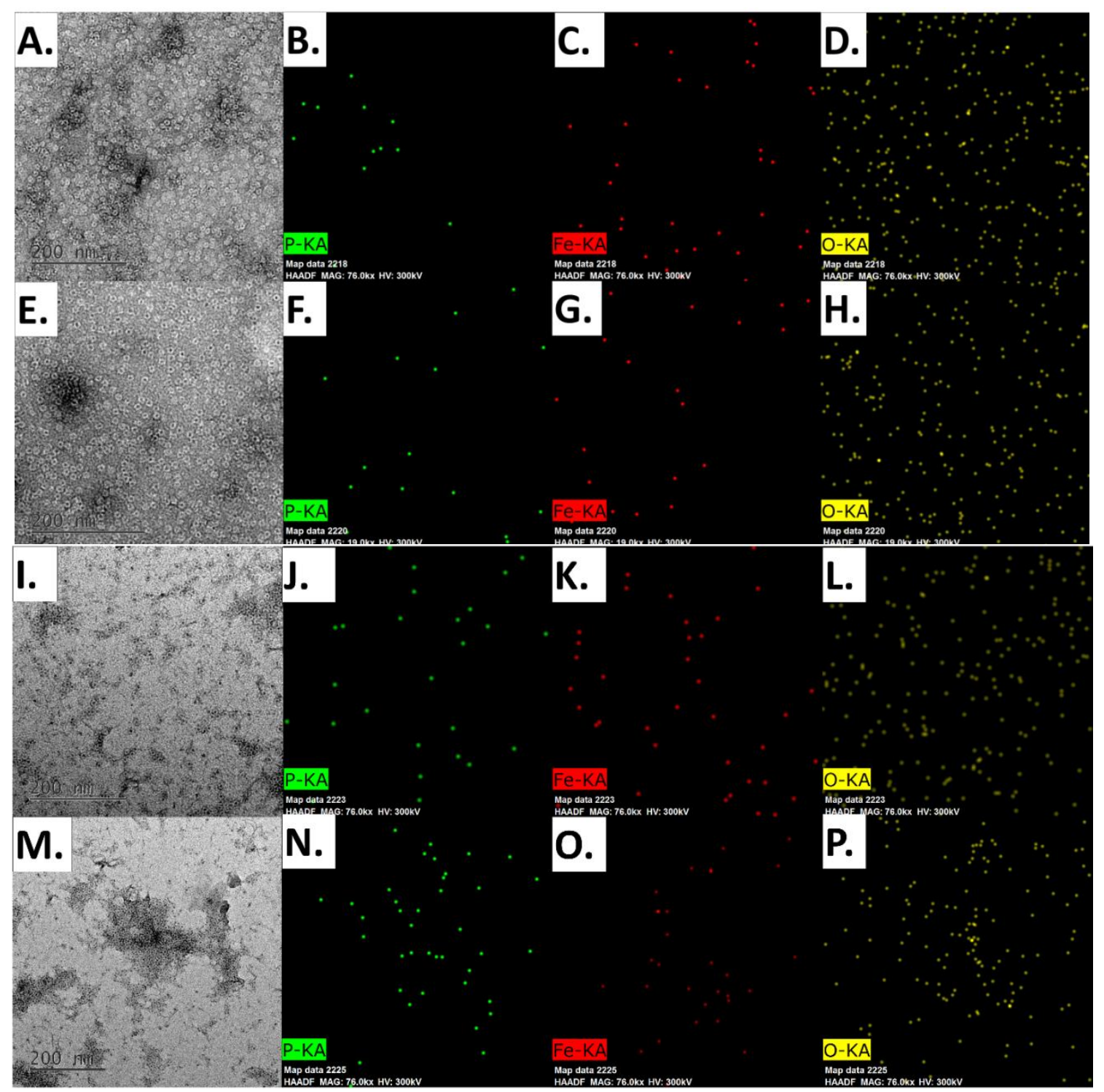

Figure S8. Elemental maps of mineralized recombinant WT Mtb BfrB protein nanocages doped with $0 \mathrm{mM}(\mathbf{A}-\mathbf{D}), 1 \mathrm{mM}(\mathbf{E}-\mathbf{H}), 5 \mathrm{mM}(\mathbf{I}-\mathbf{L})$ and $10 \mathrm{mM}$ (M-P) phosphate. (A,E,I,M) Bright field TEM images; (B, F, J, N) elemental map at the P-Ka; $(\mathbf{C}, \mathbf{G}, \mathbf{K}, \mathbf{O})$ elemental map at the $\mathrm{Fe}-\mathrm{K} \beta$ and Fe-L; (D, H,L,P) elemental map at the O-K $\alpha$.The elemental maps of each sample were collected using the same experimental setting with the difference being in the amount of phosphate addition. 


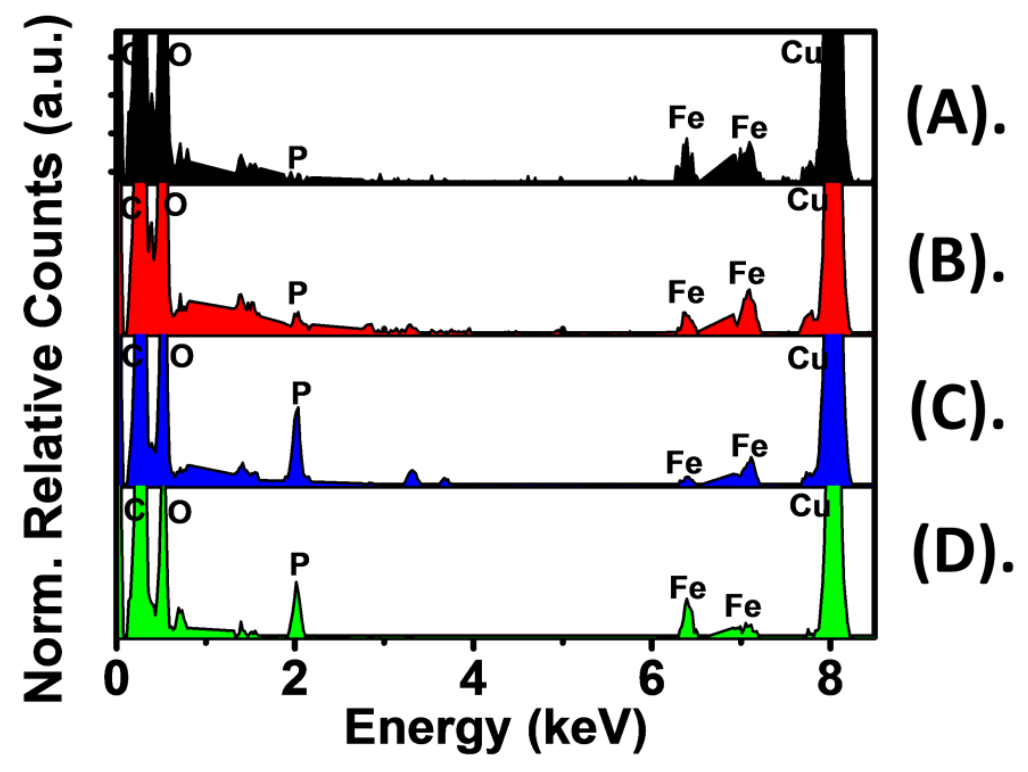

Figure S9. EDX spectra of mineralized recombinant WT Mtb BfrB protein nanocages doped with $0 \mathrm{mM}(\mathbf{A}), 1 \mathrm{mM}(\mathbf{B}), 5 \mathrm{mM}(\mathbf{C})$ and $10 \mathrm{mM}(\mathbf{D})$ phosphate.
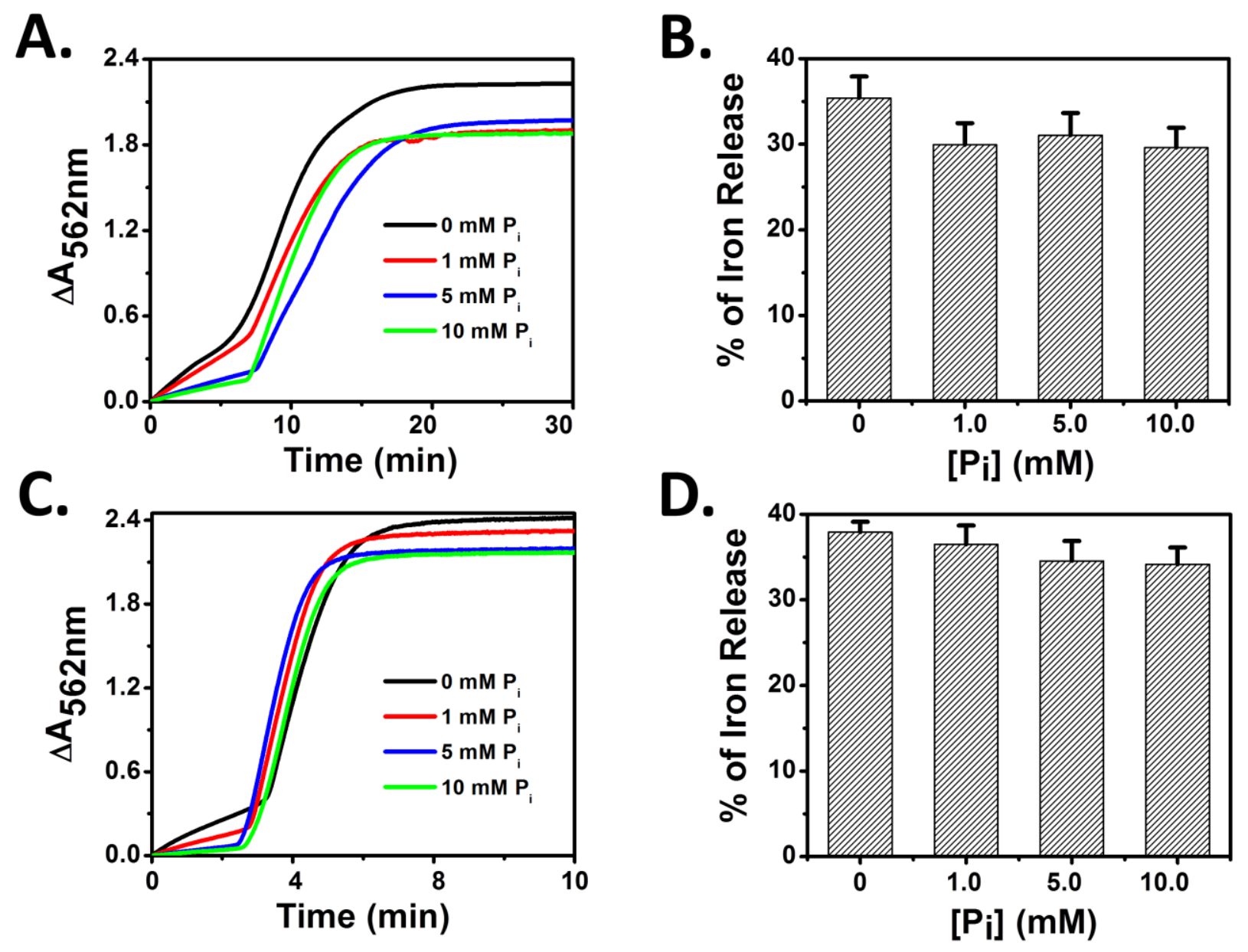
Figure S10. Reductive iron mobilization from recombinant $M t b$ BfrB nanocage upon adding phosphate after mineralization. Iron release profile from $M t b \mathrm{BfrB}$ nanocages without removal of phosphate (A) and after removal of phosphate followed by iron quantification by taking $250 \mu \mathrm{M}$ of $\mathrm{Fe}^{2+}$ from each sample $(\mathbf{C})$. Kinetics of iron release was monitored using a SHIMADZU UV-vis spectrophotometer at $562 \mathrm{~nm}$ for the formation of $\left[\mathrm{Fe}(\mathrm{Fz})_{3}\right]^{4-}$, after reduction and dissolution of the mineral core. Percentage of iron release from ferritin samples was calculated after $30 \mathrm{~min}$ for panel $\mathbf{A}$ and after $10 \mathrm{~min}$ for panel $\mathbf{C}$ and represented in panel $\mathbf{B}$ and $\mathbf{D}$, respectively. The reaction was carried out in100 mM MOPS, $100 \mathrm{mM} \mathrm{NaCl}(\mathrm{pH} 7.0)$ at $25{ }^{\circ} \mathrm{C}$ containing $100 \mu \mathrm{M}$ of FMN, $2.5 \mathrm{mM}$ of NADH, $2.5 \mathrm{mM}$ of ferrozine and Mtb BfrB having $250 \mu \mathrm{M}$ of iron.

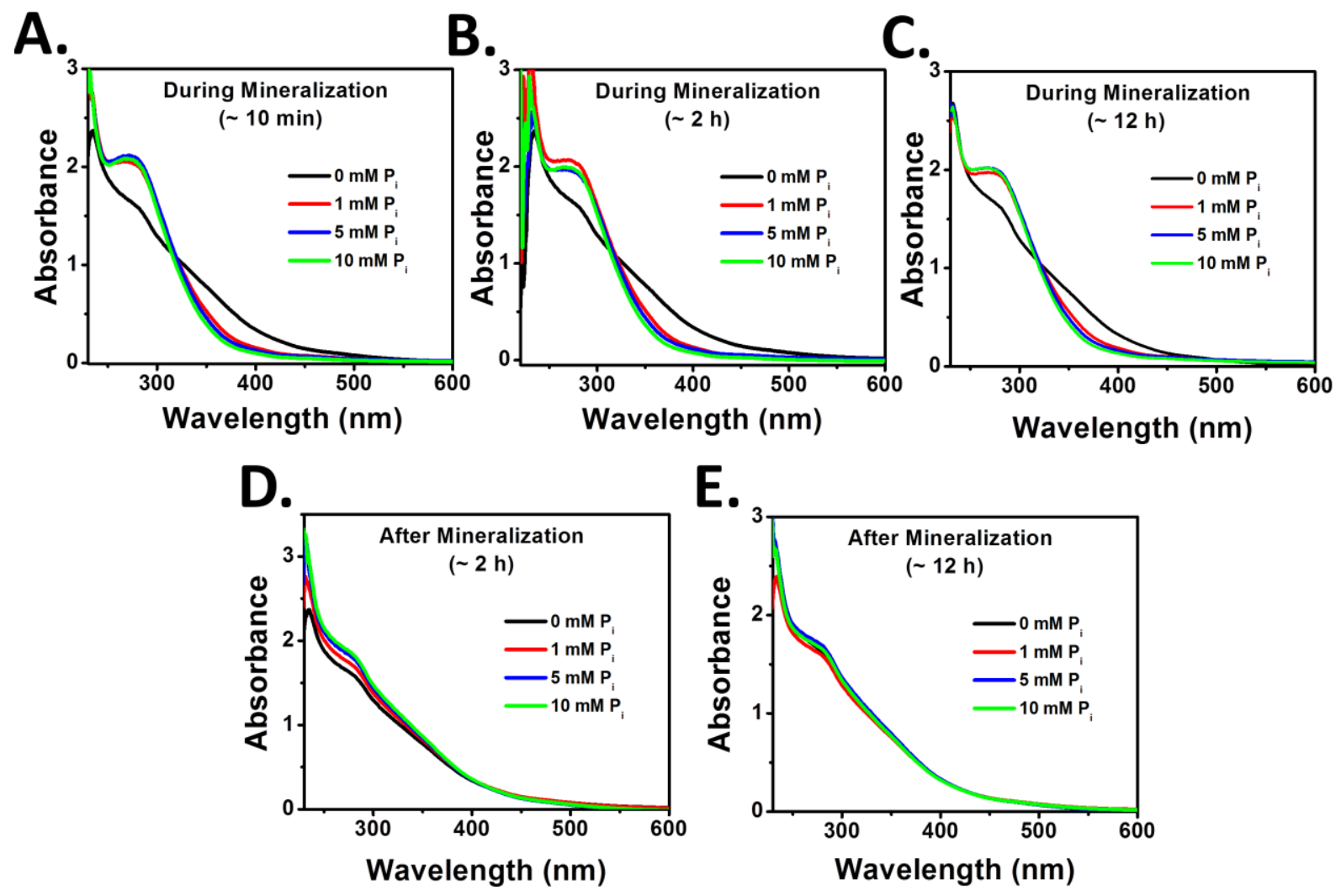

Figure S11. The spectra of mineralized $M t b$ BfrB samples, where phosphate was added during (A-C) and after (D \& E) mineralization process. The spectra were monitored using a SHIMADZU UV-vis spectrophotometer and the 'time' at which the spectra were recorded is indicated in the respective figures. Each reaction consisted of $1 \mu \mathrm{M}$ of $\mathrm{Mtb} \mathrm{BfrB}$ having 480 Fe/cage prepared in $100 \mathrm{mM}$ MOPS, $100 \mathrm{mM} \mathrm{NaCl}(\mathrm{pH} 7.0)$ at $25^{\circ} \mathrm{C}$. 

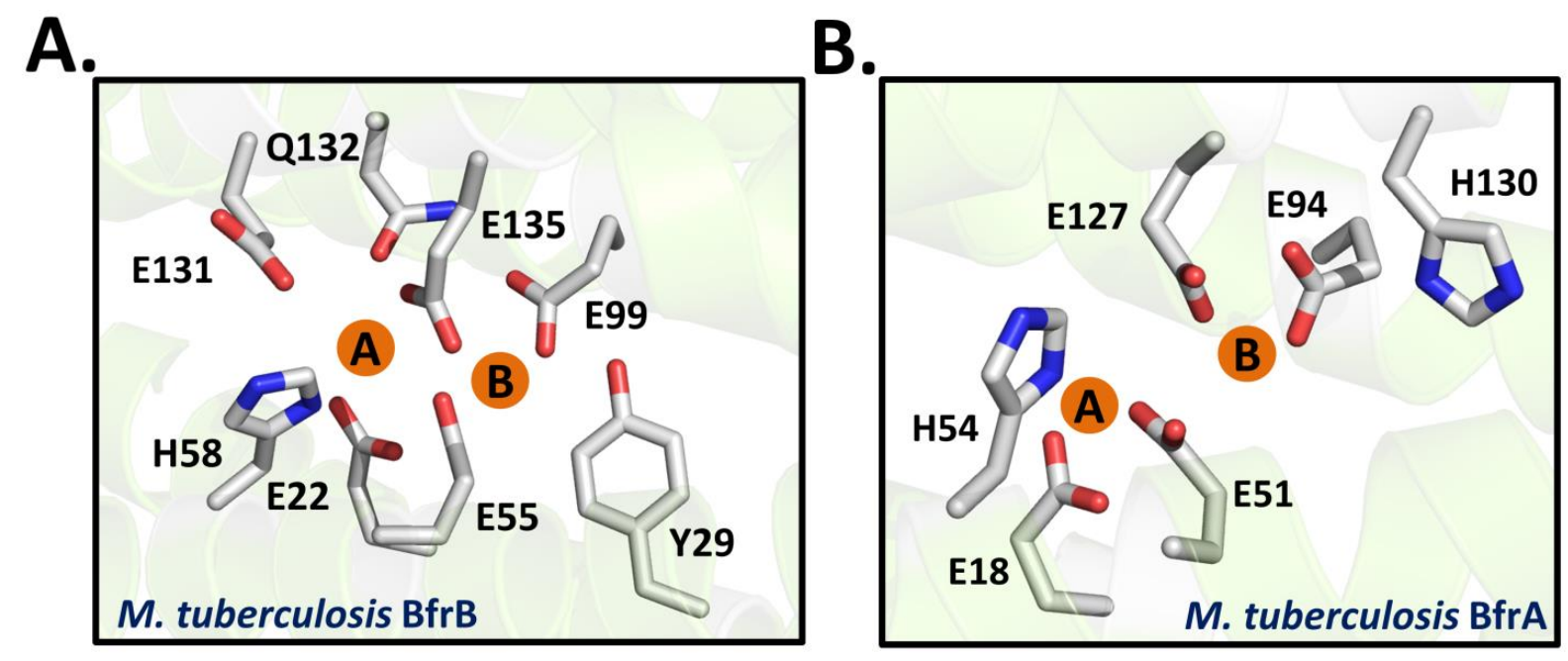

Figure S12. Models of the ferroxidase sites in Mtb Bfrs required for the rapid uptake of $\mathrm{Fe}^{2+}$ to accumulate the DFP like species in $M t b$ BfrB (A) and $M t b$ BfrA (B). The di-iron sites are labelled as ' $\mathbf{A}$ ' \& ' $\mathbf{B}$ ' in orange spheres and the amino acids residues present in the vicinity of them are shown in sticks. The figures were generated using PyMOL (Mtb BfrB; PDB ID- 3QD8 and $M t b$ BfrA; PDB ID- 3UOI). 

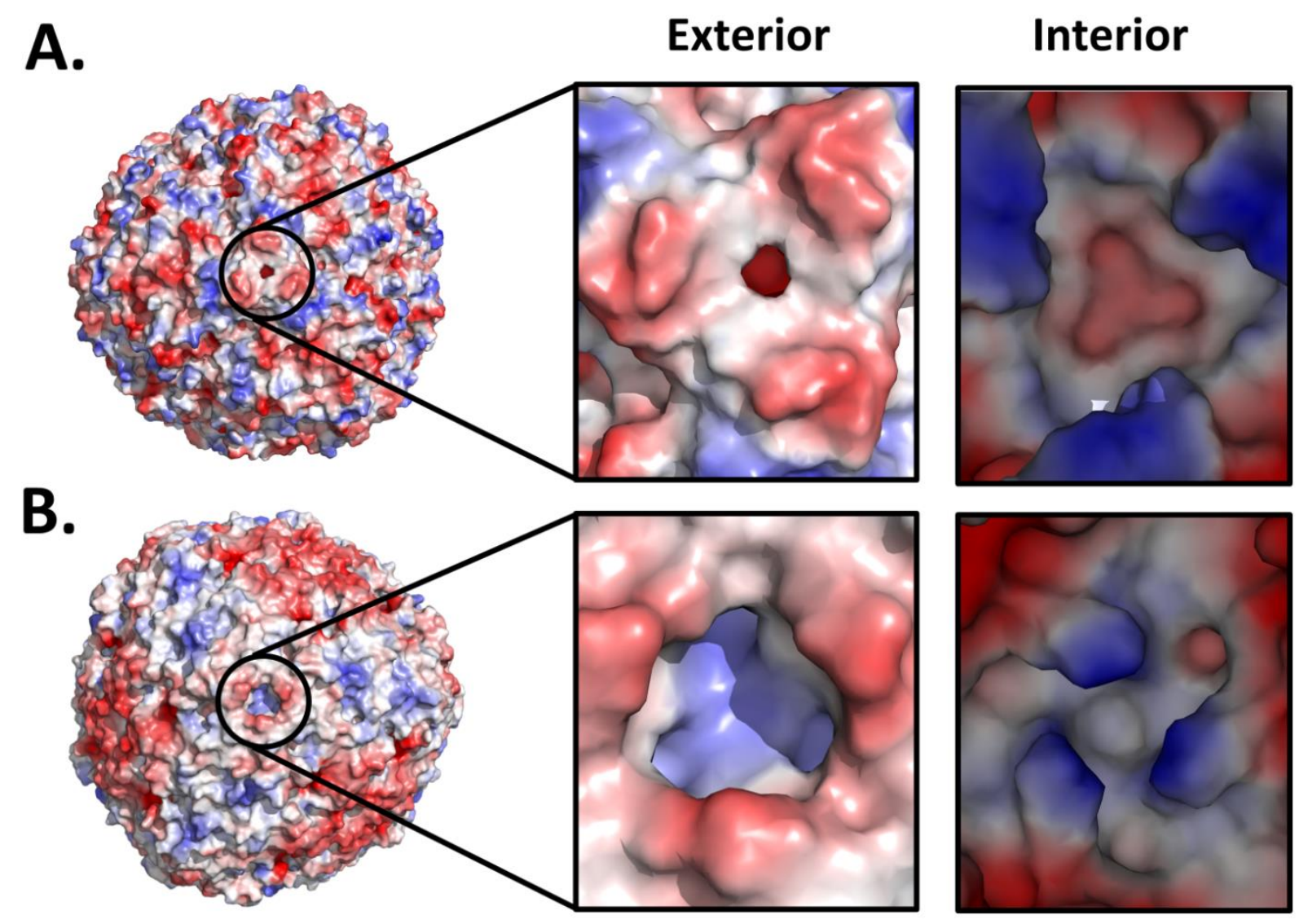

Figure S13. Electrostatic potential surfaces of $M t b$ Bfrs viewed along the $\mathbf{C}_{\mathbf{3}}$ axis. Left: $M t b$ BfrB (A) and $M t b$ BfrA (B). The surface electrostatics of $M t b$ Bfrs (zoomed) around the three fold pores, middle: external and right: internal. The surface electrostatics was generated using PyMOL (Mtb BfrB; PDB ID-3QD8 and Mtb BfrA; PDB ID-3UOI). 

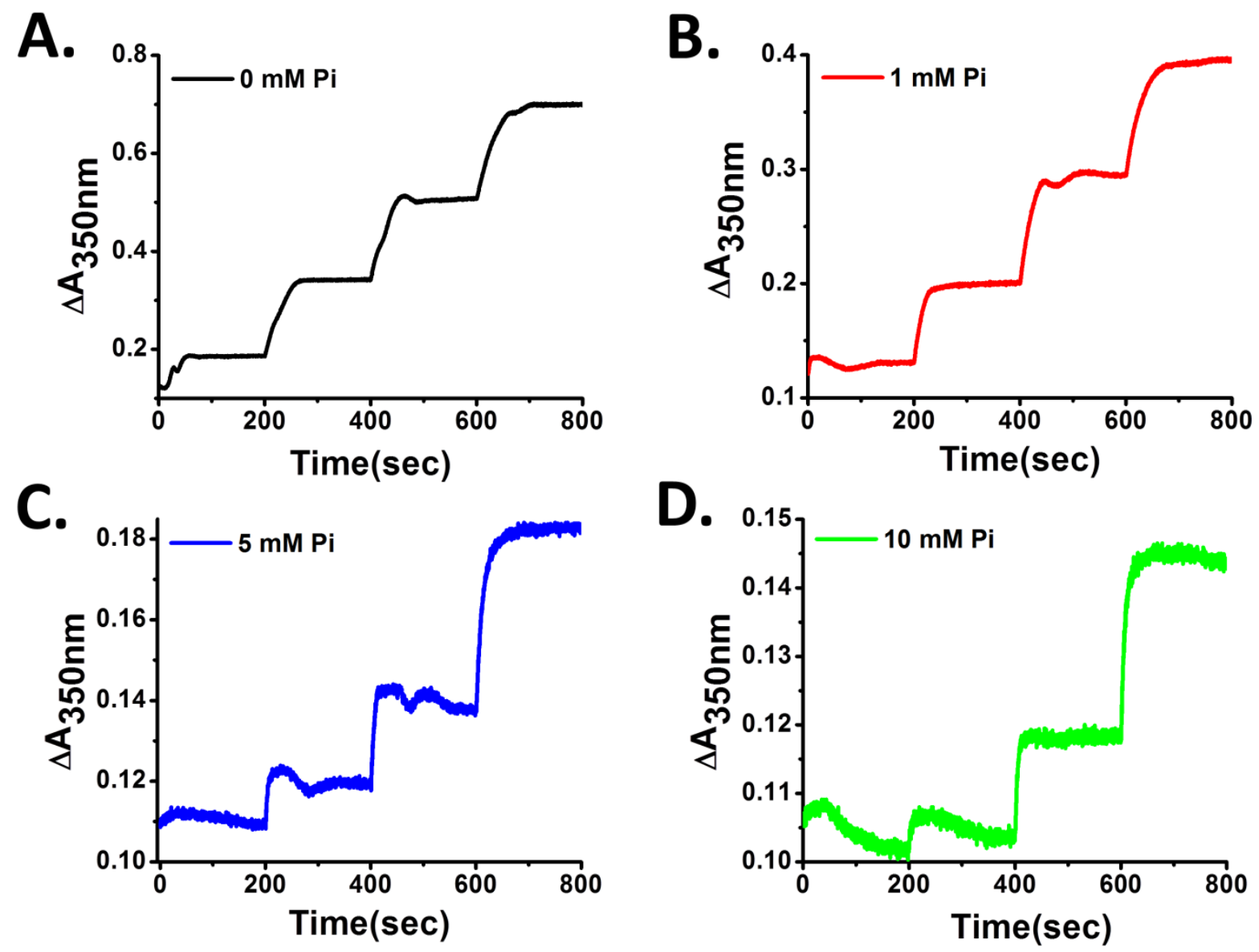

Figure S14. Iron oxidation in $M t b \mathrm{BfrB}$ in the presence of $0 \mathrm{mM}(\mathbf{A}), 1 \mathrm{mM}(\mathbf{B}), 5 \mathrm{mM}(\mathbf{C})$ and $10 \mathrm{mM}(\mathbf{D})$ phosphate by sequential addition of $120 \mathrm{Fe} /$ cage to $1.0 \mu \mathrm{M} \mathrm{Mtb} \mathrm{BfrB}$ in $100 \mathrm{mM}$ MOPS, $100 \mathrm{mM} \mathrm{NaCl}$ (pH 7.0). The absorbance changes were monitored by using SHIMADZU $\mathrm{UV}$-visible spectrophotometer at $25^{\circ} \mathrm{C}$. 